\title{
Extrapolating from an Inquiry into Curricular Issues Concerning the Adoption of English as Medium of Instruction in a Japanese University Situation
}

Glenn $\mathrm{TOH}^{*}$

\begin{abstract}
Japanese universities have lately begun to teach academic content in English instead of Japanese. In this article, I examine curricular and ideological issues related to having English as a medium of instruction (EMI) at a Japanese university before examining their links to larger cultural-political forces in Japan, including neoconservative agendas. My discussion is framed within the setting of a Japanese higher education facing the challenges of: (1) low enrolments and institutional solvency; (2) curricular reform in keeping with the need for institutional renewal. Specifically, based on a critical narrative inquiry into a workplace encounter involving two university courses, one in introductory psychology and another in English for Academic Purposes (EAP), I will explore the ideologically-embedded nature of discourses affecting professional understandings of language, meaning making and curriculum. I will also observe that the 'changes' resulting from the adoption of EMI are only superficial and that the role and status of English, in reality, remains circumscribed.
\end{abstract}

Key words: Academic content; medium of instruction; ideology; policy.

* Tamagawa University, Tokyo, Japan

Corresponding author: glenn@lit.tamagawa.ac.jp

Received: 2015-06-10 / Sent for peer review: 2015-08-06 / Accepted by peers: 2016-03-18 / Approved: 2016-06-24 To reference this article in APA style / Para citar este artículo en APA / Para citar este artigo

Toh G. (2016). Extrapolating from an Inquiry into Curricular Issues Concerning the Adoption of English as Medium of Instruction in a Japanese University Situation, 9(1), 210-235. doi:10.5294/laclil.2016.9.1.9 


\title{
Extrapolación de la investigación a los asuntos curriculares relacionados con la adopción del inglés como medio de instrucción en un contexto universitario japonés
}

\begin{abstract}
Resumen
Las universidades japonesas últimamente han comenzado a enseñar contenido académico en inglés en lugar de japonés. En este artículo, se examinan los asuntos curriculares e ideológicos relacionados con el hecho de tener el inglés como medio de instrucción (IMI) en una universidad japonesa, para pasar luego a examinar sus conexiones con las fuerzas político-culturales en Japón, incluyendo las agendas neoconservadoras. La discusión está enmarcada dentro del contexto de la educación universitaria japonesa, que enfrenta las siguientes problemáticas: (1) el bajo número de estudiantes matriculados y la solvencia institucional; (2) la reforma curricular en respuesta a la necesidad de una renovación institucional. A partir de una investigación narrativa crítica en un contexto de trabajo que involucra dos cursos universitarios, uno de Introducción a la Psicología y otro de Inglés con Propósitos Académicos (IPA), se explora, a su vez, la naturaleza profundamente ideológica del discurso que afecta la comprensión profesional del lenguaje, la construcción del significado y el currículo. También se aclara que los 'cambios' resultantes de la adopción de IMI son solamente superficiales y que el papel y el estatus del inglés, en realidad, permanecen restringidos.
\end{abstract}

Palabras claves: contenido académico; medio de instrucción; ideología; política. 


\title{
Extrapolação da pesquisa sobre os assuntos curriculares relacionados com a adoção de inglês como meio de instrução num contexto universitário japonês
}

\begin{abstract}
Resumo
As universidades japonesas têm começado a ensinar conteúdo acadêmico em inglês em vez de japonês. Neste artigo, são analisados os assuntos curriculares e ideológicos relacionados com o fato de ter inglês como meio de instrução (IMI) numa universidade japonesa, para logo passar à análise de suas conexões com as forças político-culturais no Japão, o que inclui as agendas neoconservadoras. A discussão está delimitada no contexto da educação universitária japonesa que enfrenta as seguintes problemáticas: 1) baixo número de estudantes matriculados e solvência institucional, e 2) reforma curricular em resposta à necessidade de uma renovação institucional. A partir de uma pesquisa narrativa crítica num contexto de trabalho que envolve dois cursos universitários, um de introdução à psicologia e outro de inglês com propósitos acadêmicos, explora-se a natureza profundamente ideológica do discurso que afeta a compreensão profissional da linguagem, a construção do significado e o currículo. Também esclarece que as "mudanças" decorrentes da adoção de IMI são somente superficiais e que o papel e o status de inglês, em realidade, permanecem restringidos.
\end{abstract}

Palavras-chave: conteúdo acadêmico; meio de instrução; ideologia; política. 


\section{INTRODUCTION}

This article is about language, curricular content knowledge and the cultural politics of academic English teaching in a Japanese situation. It takes the form of a teacher generated critical narrative inquiry and relates to my work in a liberal arts faculty at a Japanese university where I was EAP (English for Academic Purposes) teacher and coordinator. In particular, the article concerns a critical investigation of a workplace encounter which forms the basis of deeper professional reflections on attendant issues related to ideological, cultural and political epistemologies. The contents of the inquiry, while centred on English in a Japanese higher education situation, are relevant to situations where education policies and practices are bound up with larger and more powerful issues in cultural politics.

Japan has been facing the challenge of falling birth rates. Universities have had to merge or close because of falling enrolments (McVeigh, 2006). To counter this problem, universities have attempted to create new curricula to increase enrolments (McVeigh, 2006; Yamagami \& Tollefson, 2011; Burgess, 2010). Redesigning the curriculum by offering courses delivered in English instead of Japanese has been one way that universities have tried to be innovative. In broad terms, English in Japanese higher education has been linked to discourses of globalization, economic competitiveness as well as business and employment opportunities (Yamagami \& Tollefson, 2011). English, moreover, features prominently in policy and educational rhetoric that affirms its instrumental value in international exchanges (Kubota, 2002; Kubota, 2011a) even as Japan strives to maintain its position as an economic powerhouse in global business dealings.

However, changing the medium of instruction is, realistically speaking, not simple given the limited number of students with a sufficiently good command of English to study academic content. Japanese students learn in Japanese throughout their time in school and it has only been in the decade after the new millennium or so that EMI has gained some traction, principally in higher education (Yamagami \& Tollefson, 2011). While the advent of EMI helps universities to project a progressive image (Yamagami \& Tollefson, 2011), such universities are in competition with others adopting the same strategy, given the limited pool of students wanting 
to, and are capable of, completing degrees in English. EAP support classes are seen as a means of making the delivery of academic courses in English a viable proposition, resulting in increased offerings of campus EAP courses (cf. Jenkins, 2014). Even so, the late adoption of EMI does not occur without other accompanying challenges and ironies. These challenges and ironies are attributable to a lack of appreciation of (and preparedness for) the epistemological and ontological adjustments necessary for the (rather sudden) change in medium of instruction. As I will observe, these challenges and ironies relate as much to narrow or circumscribed conceptualizations of language, knowledge and curriculum as to nationalistic discourses contributing to insecurities in Japanese cultural politics awakened by the increased presence of a foreign language like English on university campuses in Japanese hinterland.

Despite the above concerns, universities have been recruiting teaching staff from overseas as part of concurrent attempts at faculty renewal (Rivers, 2010). In my case, I have worked alongside colleagues from the United States, the United Kingdom, Eastern Europe and the Asia-Pacific. I too was recruited as an experienced English teacher, having taught for 25 years in Australia, Hong Kong, New Zealand and my native Singapore.

In the following sections, I will first examine the literature highlighting recent changes and challenges concerning Japanese universities. I will then provide a description of the aim and contextual details of a reflexive investigation into a workplace encounter that eventually led me to the deeper professional reflections that form the basis of this article, before finally engaging in a critique of the implications of my observations vis-àvis the cultural politics of EMI in Japan.

\section{Literature review}

Japanese higher education has been known for its respect for meritocracy and efficiency in nurturing commitment and group-cohesiveness among students, leading to suggestions that American universities too should learn from its successes (Sugimoto, 2010). In recent years, universities have tried to develop their own unique character and specializations, while internationalization and increases in overseas student numbers have made 
campuses more cosmopolitan (McVeigh, 2000; Yamagami \& Tollefson, 2011; Birmingham, 2012; Masutani, 2013). The business sector has, in particular, been supportive of new energies put into strengthening student exchange programs (Masutani, 2013).

Other literature, however, has portrayed Japanese universities as being in need of reform. Such literature has typically drawn attention to: (1) outmoded curricula and delivery methods as well as over-centralized administrative procedures (McVeigh, 2002; Murphey, 2004; Sugimoto, 2010; Rivers, 2013); (2) insular and exclusionary practices against people or ideas deemed foreign or unfamiliar (Hall, 1997; Rivers, 2010 \& 2013; Yamagami \& Tollefson, 2011); and (3) superficial attempts at internationalization or institutional reform where university administrators opt for cosmetic changes while institutions continue to be conservative and intransigent (McVeigh, 2002 \& 2006; Murphey, 2004).

Such a state of affairs has been attributed to a variety of reasons including: (1) Japanese society's diligent guarding of its cultural borders through constructions of a 'Japanese Volk' (McVeigh, 2006, p. 225) or uniqueness to be found in nihonjinron writings (literally 'principles of Japaneseness'), a genre of literature promoting the primordial nature of Japanese uniqueness (Hall, 1997; Befu, 2001); (2) the country's nearly unbroken rule of almost six decades by governments dominated by the conservative Liberal Democratic Party - set in motion during Japan's post-war occupation by the Allied forces which supported a conservative mercantilist (now neoliberal) and culturally 'pure' and monolingual Japan (Hall, 1997; Dower, 1999; Caprio \& Sugita, 2007; Kubota, 2011b); (3) claims of a 'Japanese way' of thinking and understanding tied into racial and cultural constructions of Japaneseness and purity (Hall, 1997; Befu, 2001; McVeigh, 2002 \& 2006); as well as (4) conceptualizations of Japaneseness as being linked uniquely to a genetically-based proficiency in the Japanese language - to the exclusion of other languages including English (Befu, 2001; McVeigh, 2002).

In this connection (and notwithstanding affirmations of its role in Japan's global business dealings), English, apart from being the language of Japan's erstwhile post-war occupiers, has often been subsumed under nationalistic or neoconservative discourses that characterize it as a 'threat' or 'juxtaposition' to Japanese culture (Befu, 2001; McVeigh, 2000 \& 2002; 
Hashimoto, 2007; Yamagami \& Tollefson, 2011; Heinrich, 2012). However, with low enrolments, universities have begun to offer academic courses in English, the more recent turn-of-rhetoric being that English provides a way for accumulating cultural capital and better employment opportunities (Yamagami \& Tollefson, 2011).

In terms of previous research into EMI, it should be noted that EMI is not a widely investigated area in Japan due to its relative newness in Japanese higher education. By way of providing a brief summary of previous research, EMI in Japan has been investigated in relation to a range of issues. These include difficulties in team-teaching arrangements and differences in expectations between English teachers and specialist content area professors (Stewart, 2001); discourses and ideologies influencing the implementation of EMI (Yamagami and Tollefson, 2011); English teachers' views about the tenability of EMI (Toh, 2013); and very recently, the role of native and lingua franca varieties of English in EMI instruction (Iino \& Murata, 2016). Apart from these, there have also been essayist type commentaries about different socio-cultural and ideological issues by social and political commentators, including Burgess (2010) and Birmingham (2012), which problematize English medium instruction in Japan.

In relation to my present discussion, the above literature raises important issues relevant to my reflexive critique, of which the following critical investigation is a pivotal part.

\section{METHOD}

\section{Context}

The investigation is set in a liberal arts faculty of a university in the Kanto region where courses in the humanities and social sciences, including international relations, anthropology and psychology are taught in English. The liberal arts bachelors program offered by the faculty aims to enable students to work in areas such as tourism, international relations, aid and development. The investigation concerns both professional and policy-related implications of a critical encounter linked to my work responsibilities. Through this investigation, I seek to better understand the institutional 
and ideological forces influencing decisions concerning EMI, their implications for the practice of EAP teachers, as well as for larger issues linked to language, ideology and cultural politics.

\section{Approach}

In terms of approach, I adopted a two-staged or two-pronged strategy to help me understand: (1) the situational and exigent realities; and (2) the ideological forces behind a work-related encounter involving a course in introductory psychology. The first stage involved the composition of a vignette of the critical encounter, relating specifically to the psychology professor's communication with me in my capacity as English teacher and coordinator.

The use of the vignette in qualitative inquiry is explained in Dörnyei (2007), who notes that the vignette, like the analytic memo, is an exploratory and analytical tool in qualitative inquiry. Dörnyei (2007, p. 254-255) describes vignettes as short narratives that 'provide focused descriptions of events or participant experiences' often used by researchers to 'grow the ideas' and to see them develop into deeper themes of investigative study. In my case, these deeper themes are discussed in the sections following 'Larger Professional and Ideological Discourses' where I further explore my observations vis-à-vis professional culture and prevailing societal discourses. My use of vignettes would, therefore, be in keeping with the social role of stories and storytelling in research (Gray, 2002, p. 107), to facilitate epistemological 'understandings of the processes of culture and meaning in society'.

The second stage involved my drawing on the interrogative methodology adopted in studies on professional vision, applied in Goodwin (1994). Goodwin (1994) described the way coding and categorization can be used to investigate new phenomenal environments or situations in professional contexts. In a later section, I will illustrate in detail how highlighting, coding and categorization can be used to mark out professional turf and territory while revealing power differentials and contestations over professional perception (Goodwin, 1994), when their significance becomes clearer. Suffice to say now that a better understanding of professional and power is- 
sues within institutions can be achieved through investigative protocols that help to uncover professional perception and vision.

In taking the above approach to critical discursive inquiry, I have followed other investigative works by language teachers seeking the use of stories, vignettes and critical incidents to enrich existing discussions on: (1) language, ideology, cultural politics (Spack, 1998; Murphey, 2004; Hayes, 2010; Rivers, 2013; Giri \& Foo, 2014); (2) teachers as agents of dialogue and transformation in the face of institutional or cultural-political asymmetries and agendas (Murphey, 2004; Alderson, 2009; Kubota \& Fujimoto, 2013). I am also guided by Gray (2002) who, while making observations about research methodology, highlights the value of sustaining a 'double move between an ontological register, a way of being in the world based on experience, and an epistemological register through which that being/experience can become a way of knowing' (Gray, 2002, p. 114).

In the following section, I will first provide the vignette before turning to Goodwin's (1994) coding and interrogative techniques to explain salient aspects of my critical encounter.

\section{Critical incident}

Start of Vignette. As part of my initial orientation, I had to meet faculty professors in charge of various EMI courses. One psychology professor, a venerable gentleman from an English-speaking country with many years in Japan, showed particular keenness in the way the EAP Reading program would provide support for his Psychology Core course. I was duly shown the course website which had a week-by-week breakdown of topics and links to important concepts and vocabulary including the 'Psychology Vocabulary List' for each lecture, the 'Overview-Keys', 'Advanced Organizer' and the 'Summary-Recite' sections. I was informed that I should base my worksheets on information drawn from this website and that my course would have a working moniker, the 'Core Link', to emphasize its linkage to Psychology Core. To summarize our discussion, the professor sent me a confirmatory message reiterating the points discussed.

In the message, I was reminded that there would be nine classes for the Core Link compulsory for all freshmen, except those demonstrating 
good English proficiency. The classes would be divided using the TOEIC (Test of English for International Communication), a standardized test used by businesses and universities. Similarly, for Psychology Core, the professor said that he would stream students according to English proficiency. For those proficient in English who would be exempted from EAP by the administration, the professor said that he would himself conduct a supplementary class for them. He noted that despite their better English, these students would lose out if he did not give them supplementary lessons.

The professor also raised the following concerns. He said that apart from me, the other Core Link teachers were part-timers. His worry was that part-timers were difficult to reach. He had previously endeavoured to help part-timers with Core Link planning but found them rarely on campus. He said that he was prepared to guide us again so that we would be clear about how his website materials might be used. He noted that Psychology and other core courses were not effective previously because of the absence of an EAP coordinator, making communication difficult. He said that he was busy revising his materials for the start of semester. While emphasizing that preparation of the Core Link worksheets remained the responsibility of the EAP teachers, he expressed concern about their content and his desire to know what the EAP teachers would do with them.

Soon after our meeting, a fresh cohort of 180 eighteen-year-olds sat for their TOEIC test. The results revealed a worryingly wide range of scores spanning pre-intermediate to advanced levels. Students at lower proficiency levels would find it extremely difficult to engage with psychology material in English. End of Vignette.

\section{RESULTS}

\section{Defining professional vision}

The psychology professor's communication represents a fairly normal workplace transaction where one party seeks to secure the initiative (and hence advantage) of definitive utterance, which according to Goodwin (1994, p. 613) gives the initiator the benefit of being able to create 'an interpretive environment that [would] be used by participants to analyse 
whatever occurs after it'. However, as will be seen, what the professor attempts to do also signals concerns about language, meaning making and professional vision.

Understandably, the setting was contextually amenable to something like this happening. A new cohort of students would soon enter university. I was a new teacher and coordinator where previously, there was no coordinator. I was also the only full-timer teaching Reading. These constituted factors that signalled a new phenomenal environment that had to be defined, coded and interpreted, on which professional insignia and imprint would have to be staked and if necessary, contested (Goodwin, 1994). Gee (2000) captures what he sees as the nature of such contestations:

We attempt to get other people to recognize people and things as having certain meanings and values within certain configurations or relationships ...We attempt, through our words and deeds, to get others to recognize people, things, artefacts, symbols, tools and technologies, actions, interactions, times, places, and ways of...valuing as meaningful and valuable in certain ways. (Gee, 2000, p. 191)

Goodwin (1994) describes how people in the professions exercise power by staking claims on professional territory through the practice of coding and highlighting to shape events in the phenomenal environment being examined. He notes that perceptual fields in the professions are not transparent but are discursively constituted. Coding is used to transform materials being observed into objects of knowledge that can then be used to animate the discourses of the profession. Coding and categorizing thus become important tools to organize ways of seeing and perceiving (Goodwin, 1994). Highlighting can furthermore be used to make salient specific phenomena in a complex perceptual field, through the work of marking or making prominent. Goodwin (1994) further describes how archaeologists draw lines in the sand to construct visible annotations in general patches of what essentially is dirt to a layperson or even a farmer. Such visible annotations are then used to guide the perception of others, "reifying [an] object that the archaeologist proposes to be visible in the...dirt" (Goodwin, 1994, p. 611). People in professions also delineate professional vision 
- socially organized ways of understanding events promoting distinctive interests of particular groups - through producing and articulating representations of the putative event or phenomenon. Akin to how ideology operates, meaning and signification are mobilized in the interests of sustaining relations of power (Thompson, 1987). Simply put, people in professions mark out territory by coding, categorizing, 'calling out', highlighting and representing events or phenomena in ways advantageous to them. Much like Goodwin's (1994) archaeologist who categorizes soil, the psychology professor can be observed to be teasing out the phenomenal environment by making calls and categorical pronouncements on its nature.

\section{Analysis of codings and categorizations}

In his communication, the professor recognizes three categories of classes: the Psychology Core lectures, EAP Reading classes, and the supplementary class he would run for those exempted from EAP. Also, the professor did not refer to the EAP Reading classes as such. He called them the 'Core Link'. Following Goodwin's (1994) work on coding and highlighting, I attempt to further understand the critical incident and the professional implications thereof. I will first identify the codings identifiable from the professor's communication (Table 1) before commenting on them in the Discussion section.

\section{DISCUSSION}

The above observations, while not unusual of the power-laden nature of institutional interaction (Drew \& Heritage, 1992; Barton, 2007), attract deeper analysis when viewed in the light of how ideology and power can influence teaching and planning. Workplace encounters are often manifestations of larger institutional asymmetries and ideological discourses (Drew \& Heritage, 1992). In seeking to link phenomenal experience with epistemological meanings, I feel that it is important to avoid allocating 'blame', for example, on people like the professor. To do so would be to lose sight of the valuable inferences to be drawn from a deeper understanding of institutionally and politically located discourses and histories that very likely precipitate or perpetuate human actions and behaviours. 


\section{Table 1. Coding.}

\begin{tabular}{|c|c|}
\hline $\begin{array}{l}\text { Coding One: } \\
\text { Materials-mine, } \\
\text { Materials-yours }\end{array}$ & $\begin{array}{l}\text { The professor distinguished between the materials for his } \\
\text { lectures which he spoke about as being revised for the start } \\
\text { of semester and materials for the Core Link. In the course } \\
\text { website, he constructed links to important sections like the } \\
\text { 'Psychology Vocabulary List', 'Overview-Keys', 'Advanced Or- } \\
\text { ganizer' and 'Summary-Recite', assigning nomenclature } \\
\text { which Fairclough (2001) notes to be often used as stakes of } \\
\text { professional turf. The materials for the Core Link were to be } \\
\text { prepared by the EAP teachers, but were spoken of specif- } \\
\text { cally as having to be garnered from the psychology website. }\end{array}$ \\
\hline $\begin{array}{c}\text { Coding Two: Core } \\
\text { Course and Core link }\end{array}$ & $\begin{array}{l}\text { The professor spoke of the core course as being under his } \\
\text { purview and the Core Link, about which he was extreme- } \\
\text { ly concerned. It was noticeable in his communication that } \\
\text { the professor wove in and out of wanting a say in the Core } \\
\text { Link while distancing himself from aspects of it like work- } \\
\text { sheet preparation. This is indicative of a struggle in want- } \\
\text { ing influence over matters concerning the language classes } \\
\text { while not wanting to be part of what he ostensibly (and } \\
\text { rightly) felt was not his job to do (materials preparation for } \\
\text { English teaching). }\end{array}$ \\
\hline $\begin{array}{l}\text { Coding Three: } \\
\text { EAP Groupings, } \\
\text { Psychology Streams }\end{array}$ & $\begin{array}{l}\text { The professor intended to stream the students. Like the EAP } \\
\text { groupings, he intended to stream the Psychology Core stu- } \\
\text { dents according to their TOEIC test performance. }\end{array}$ \\
\hline $\begin{array}{l}\text { Coding Four: Full- } \\
\text { timer, Part-timer }\end{array}$ & $\begin{array}{l}\text { The professor commented on the employment status of the } \\
\text { teachers: the one full-timer vis-à-vis the part-timers. His con- } \\
\text { cern was that the part-timers would be difficult to reach if } \\
\text { he wanted to tell them about the website or when he need- } \\
\text { ed to help them plan their lessons. }\end{array}$ \\
\hline $\begin{array}{c}\text { Coding Five: } \\
\text { Professor, } \\
\text { Coordinator roles, } \\
\text { Teachers }\end{array}$ & $\begin{array}{l}\text { The professor noted that there was previously no Core Link } \\
\text { coordinator. Conscious of this vacuum, he took it upon him- } \\
\text { self to fill this role-having endeavoured to provide as much } \\
\text { support as he could to the teachers. He told me as coordina- } \\
\text { tor that he was still prepared to meet the Core Link teach- } \\
\text { ers for a similar purpose. }\end{array}$ \\
\hline
\end{tabular}


In terms of the recent history noted earlier, EMI has been seen as a way of increasing enrolments and shoring up university finances. This higher profile given to English, however, appears to contradict prevalent rhetoric of a conservative nature which has equated Japanese culture solely with the Japanese language (Befu, 2001; McVeigh, 2002; Hashimoto, 2007). Japanese government policy has in principle sought to reify a monolingual and monocultural Japan through careful management of cultural forms deemed alien, including the English language (Befu, 2001; Hashimoto, 2007; Hino, 2009; Yamagami \& Tollefson, 2011; Heinrich, 2012). I will revisit this issue in a later section where its relevance to the discussion will become clear.

Meanwhile, I return to my discussion of the earlier observations, guided by: (1) the literature on power asymmetries and academic literacy practices; (2) larger cultural-political discourses including the aforesaid conservative rhetoric, which need to be kept in mind given their link to discourses of Japanese monoculturalism and the notion of English as a foreign or alien cultural form (Kubota, 2011b; Rivers, 2013).

\section{Current understandings in academic literacies}

\section{Coding One: Materials-mine, Materials-yours}

The professor wanted EAP lessons to follow psychology content. He wanted to meet the teachers and have access to them, including the part-timers, but then quickly stated (the obvious) that it was not his responsibility to prepare EAP materials, while still wanting to be in the loop about them.

Such an anomaly is reconcilable if one sees a static conceptualization of academic content coupled with strong ownership of the same, alongside the felt need to influence what English teachers would be teaching, while staying aloof of worksheet preparation. Such a position is reminiscent of the belief that discipline-specific courses (in this case, psychology) inform the content of EAP - which has 'no authentic content' (Zamel, 1998 b, p. 257) of its own. The assumption projected here is that EAP teachers would (as it were) 'chew the cud' of subject-specific content and somehow convert such content into the doable worksheets and activities of an English lesson. Such a position also suggests a monolithic view of knowl- 
edge, where knowledge and subject-specific content are seen as static and unmalleable, hence precluding any possibility for discursive negotiation of meaning, which is more in keeping with the nature of higher education inquiry (Benesch, 1996; Street, 1999; Lillis, 2003; Edwards \& Usher, 2008).

Furthermore, the psychology materials that the professor said he was revising appear to work very much like what Gee (2000, p. 192) calls the 'tools' that 'mediate human action and thinking'. Using the psychology materials as a tool of leverage, the professor sought to exercise influence ('action') over the teachers' preparation in that the materials should be conceived of ('thinking') as being the basis for lesson preparation.

Benesch (2001) observes how views of EAP teachers as conduits employed to package and transmit language lessons draw on an oversimplification of academic knowledge as stable and autonomous. Zamel (1998b) also notes the tendency to view language teaching as 'packaged and formulaic' making it necessary to change the perception that language teachers 'fix the students' problems' ahead of admission to academic courses (Zamel, 1998b, p. 259). It is therefore important that the professor's communication be viewed as a part of a larger ideological narrative rather than as simply being random, incidental or idiosyncratic.

\section{Coding Two: Core Course and Core Link}

The professor's reference to Psychology Core and the Core Link is a reminder of the existence of power differentials between 'faculty' and 'language support'. The professor relegates the status of EAP to a 'supplementary class'. This equation is made inadvertently in his reference to his supplementary class for students exempted from EAP. Students exempted from EAP would still need another means of support, coming in the form of his supplementary class. What comes across is that EAP classes are de facto remedials or tutorials. This is corroborated by the Core Link moniker, reminiscent of how faculty courses are spoken of as 'core', the mainstay of university, while language courses are there to 'prepare students for the 'real' work of...university' (Zamel, 1998a, p. 192).

\section{Coding Three: EAP Groupings, Psychology Streams}

The psychology lectures would be delivered in smaller groups with streaming based on language ability. The question to be asked is wheth- 
er such streaming might not as well be based on aptitude for psychology. Such a course of action suggests conflation of language ability with ability in another subject area or a case of what Zamel calls an inability 'to get past language' (1998b, p. 252). Language proficiency is reductively equated with student ability. An Art History professor's observations are worth revisiting here:

My experience with teaching ESL students is that they have often not received adequate English instruction to complete the required essay texts and papers in my classes. I have been particularly dismayed when I find that they have already completed 2 ESL courses and have no knowledge of the parts of speech or the terminology that is used in correcting English grammar on papers. I am certainly not in a position to teach English in my classes. (The problem has been particularly acute with Chinese/S.E. Asian students.) These students may have adequate intelligence to do well in the courses, but their language skills result in low grades. (I cannot give a good grade to a student who can only generate one or two broken sentences during a ten-minute slide comparison.) (Zamel, 1998b, p. 252)

The Art History professor says that she is not in a position to teach English and yet grades students based on their English, 'thus missing the irony of grading on the basis of that which she acknowledges she is not 'in a position to teach" (Zamel, 1998b, p. 253). Land and Whitley (1998, p. 136) similarly warn of the danger of professors having what they term ' $a$ hidden agenda', that of thinking that students are only as good as their English. In the present case, English ability is used for streaming students whereas the subject in question is psychology.

\section{Coding Four and Five: Full-timer, Part-timer, Professor, Teacher}

Relationships between language teachers and faculty have been analysed in terms of power asymmetries (Benesch, 2001, p. 53), where unequal power relations are realized through teachers' supposed (lower) positioning in the hierarchy (Benesch, 2001). Stewart's (2001) discussion on team-teaching 
between subject specialists and English teachers in western Japan notes how hierarchical differences create problems.

Such inequalities are once again institutionally ingrained. Calling for change, Benesch notes that analysing power relations helps EAP teachers and faculty imagine better alternatives to the one-dimensional conceptualization of EAP as a 'service to higher-status disciplines' (2001, p. 55). In Japan, the relative urgency of having students attain a level of English for academic study means that part-time teachers will often be employed to meet staffing shortfalls, accentuating hierarchical differentials between professors, full-timers and part-timers.

\section{Larger professional and ideological discourses}

What else can be drawn from the above observations? Quite apparently, given Japan's monolingual education system, EMI is not an entirely straightforward matter for Japanese higher education.

With a history of protecting its own cultural borders and uniqueness and its cautious introduction of English language lessons into its school system (Kubota, 2011b), universities adopting EMI compete for a limited pool of students with sufficient English for university study. Some invariably lower their admission standards to support institutional cash-flow (Yamagami \& Tollefson, 2011). In cases where students with low proficiency levels are admitted, the urgency of having them understand lectures may mean that English teachers are required to help students process lecture material. Often, as has been my experience, the success of English programs is measured in coldly utilitarian terms and variously conflated with the 'success' of EMI, the attainment of enrolment quotas and university solvency. At national level, the difficulties are compounded by the fact that English has at times been viewed suspiciously as threat to Japanese culture by nihonjinron proponents (Hashimoto, 2007; Yamagami \& Tollefson, 2011).

Moreover, given the low proficiency levels, EAP teaching is liable to be carried out on readymade assumptions that language is disembodied, technical or transparent (Lillis \& Turner, 2001; Scott \& Turner, 2004; Jenkins, 2014), breakable into smaller bits of information like grammar, punctuation, paragraphing, that can be packaged into drills for students (Zamel, 
1998b; Lea \& Street, 2000; Cumming, 2003). Scott and Turner (2004, p. 62) describe language's 'non-problematic...taken-for-grantedness' and the way it can be seen reductively 'as a necessary adjunct' or 'conduit' for meaning. Views of academic literacy as a set of skills transparent and transferable during regular or remedial lessons further fuel the belief that time spent drilling them will somehow help students overcome difficulties with academic content. An EAP that is cast by force of circumstances in a support and remediation role (Jenkins, 2014) has been common in my experience.

My point here is that the professor's communication may well be a part of larger discourses that reify similar views of language teaching as drill, support and remediation. Being prevalent and influential, such discourses are more than likely to sustain actions and behaviours that come across as being presumptuous or importune, all the more so in cases where the actors concerned are in positions of ascribed or assumed power, like the professor. Moreover, the university's overall quest for more enrolments transposes itself into aspirations for a 'stellar' EAP program supporting 'stellar' academic courses in English. Such a presumptive arrangement in turn calls for seamless delivery of EAP lessons by (subjectively speaking) silently compliant English teachers to (subjectively speaking) model students studying under (subjectively speaking) brilliant professors in a 'model' university that teaches in English. Such a university would epitomize a 'progressive' institution that thrives and shines in a financially-difficult environment - albeit with unfortunate implications for (1) the commodification of EAP and EMI, and (2) the credibility and ethicality of such a move (McVeigh, 2002 \& 2006) given Japan's bespoken track-record of monolingualism, guardedness against English and other things foreign (Befu, 2001; Heinrich, 2012).

\section{Implications for deeper dialogue}

What are the implications of the issues uncovered in the above discussion? Needless to say, the inconsistencies and contradictions surfacing through the analysis suggest a need for deeper dialogue to promote greater fairness and equity among stakeholders. Professors and teachers may at times be virtually scripted to function within the circumscribed parameters of 
a system that blindsides them from fulfilling more productive or imaginative roles.

To be sure, dialogic freedom can prove elusive when one operates under the weight of powerful institutional and cultural-political discourses, contradictory though they may be. Voice, initiative and agency will need to be recovered by those who have been silenced or disempowered (Freire, 2000; Benesch, 2001; Lin \& Luk, 2005). Productive dialogue that recognizes the embodiedness of curricular content, the situatedness of human experience and the diasporic nature of knowledge (Edwards \& Usher, 2008) - all of which augur better chances for the sustainability of university reform initiatives - should be encouraged.

As it stands however, the institutional discourses uncovered in this discussion present a rather monologic relationship between language and understandings of knowledge and meaning. As far as the virtues of dialogue, imagination, mutual engagement and openness (Peters \& Roberts, 2012) are concerned, the late introduction of EMI and the apparently circumscribed role ascribed to dialogic engagement in the curriculum may well create an impression of contrivedness or inauthenticity borne of hastiness or lack of insight (foresight) on the part of decision makers. This is not to withstand the possibility of another interpretation, one that has come to mind over the course of my inquiry - which is that keeping EAP technicised, circumscribed and disengaged may well be a way of curbing or containing the overall influence of English, all too consistent with insular views of English as a threat to Japaneseness (Hashimoto, 2007; Yamagami \& Tollefson, 2011). If this surmise is correct, then it could well be the case that institutional beliefs and practices that sustain the narrow conceptualizations of EAP and EMI may actually be party to larger a conservative agenda of containing English as an alien language, while tapping superficially (and mercenarily) on its perceived instrumental benefits. Such a view would moreover explain the element of inauthenticity highlighted earlier, one that borders on the hypocrisy of having courses taught in English (for reasons to do with finances) while denying students (and teachers) the real opportunities for deeper inquiry and dialogue. One is led to conclude that EMI and the supposedly greater role for English can be both su- 
perficial and cosmetic where there is fundamentally little change in terms of the quality of academic inquiry.

Hence, if only for the sake of regaining credibility, opportunities have to be opened up for dialogue, deeper negotiation and inquiry (Edwards \& Usher, 2008) involving students, teachers and professors (Benesch, 1996). Student voices and subjectivities should be factored into planning and decision-making as part of their education. Benesch observes that 'students are so rarely consulted about...issues in academic courses...EAP follows traditional procedures, taking its cues from institutional requirements rather than student feedback' (2001, p. 52). Adopting approaches that recognize the constructed and diasporic nature of curricular content knowledge (Edwards \& Usher, 2008) and allowing (re)construction, (re)interpretation and (re)appropriation of such knowledge would be useful to this end. Teachers can also help students relate to academic material in ways that are meaningful for them, bearing in mind that course targets and objectives can be worked around to incorporate students' aspirations and teachers' imagination.

An example of such openness worth revisiting (because it brings together professor, English teacher and students) is found in Benesch's (1996) account of her experience teaching an English program for second language learners linked (however coincidentally) to a psychology survey course. The course covered content topics like brain and behaviour, perceptions, motivation and emotion, taught by a Professor Richter (pseudonym). Due to funding cutbacks, there were no tutorials and Professor Richter had to lecture to a group of 450 students. Recognizing this less-than-ideal situation Benesch encouraged students to find a way to enter into dialogue with the professor. Students wrote questions which the professor happily answered during lecture time including questions that clearly demonstrated the situatedness of their own understandings of the curricular material: 'Why do I sometimes get angry about nothing?', 'How come a person's childhood sometimes affects their adulthood in a bad or good way?', 'Is behaviour determined by our environment, or do we choose the way we behave?' (Benesch, 1996, p.733). These questions enabled some shift of control over the psychology material from professor to students (Benesch, 1996). Also, Professor Richter visited the English class and shared about his up- 
bringing as a child of Russian-Jewish parents. His visit was an occasion for humour and anecdotes which facilitated dialogic co-construction of curricular content knowledge.

\section{CONCLUSION}

In this article, I have attempted to extrapolate from my critical inquiry deeper understandings of the power-laden workings of language, ideology, meaning and cultural politics with reference to my particular situation in a Japanese institution. As matters unfolded in my workplace, it became apparent that the supposedly greater role for English on campus was in reality a matter of deploying EMI as a cosmetic front or livery for campus renewal, judging by the absence of true opportunities for academic inquiry. No less ironic, too, was the way EMI's supposed innovativeness and novelty were undermined by incompatibly narrow conceptualizations of EAP and the consequent silencing of EAP teachers and the students they teach.

As is apparent from the matters raised in the discussion, policy decisions with regard to language and content instruction, however urgent (financially) as was the case with the university concerned, are not free of issues implicating language, cultural politics and socio-histories. Surfacing these matters for reflexive discussion as I have tried to do will hopefully help to break the perceptional gridlock that comes with reductionist views of professional vision, made visible in the present critique as dissimulating the workings of conservative influences bearing heavily on institutional realities. The hope and quest for larger discursive spaces for more open dialogue at teacher and student level (like with Professor Richter) must involve the work of uncovering histories and agendas silencing such dialogue. Such transformational work will hopefully engender a release of positive energies towards the empowerment and enlightenment of the precious people concerned.

\section{REFERENCES}

Alderson, J. (2009). The micropolitics of research and publication. In J. Alderson (Ed.), The politics of language education: Individuals and institutions (pp. 222-236). Bristol, UK: Multilingual Matters. 
Barton, D. (2007). Literacy: An introduction to the ecology of written language. Malden, MA: Blackwell.

Befu, H. (2001). Hegemony of homogeneity. Melbourne, Australia: Transpacific.

Benesch, S. (1996). Needs analysis and curriculum development in EAP: An example of a critical approach. TESOL Quarterly, 30(4), 723-738.

Benesch, S. (2001). Critical English for academic purposes: Theory, politics and practice. Mahwah, NJ: Erlbaum.

Birmingham, L. (2012, September 17). Learning curve: With a push, Japan's universities go global. Time World Online. Retrieved from http:// world.time.com/2012/og/17/learning-curve-with-a-push-japansuniversities-go-global/

Burgess, C. (2010, March 23). Higher education: Opening up or closing in? Contradictory reform goals could scotch chances of success. The Japan Times. Retrieved from http://www.japantimes.co.jp/ community/2010/03/23/issues/higher-education-opening-upor-closing-in/\#.Uy1xtdiKA1I

Caprio, M., \& Sugita, Y. (2007). The US occupation of Japan: innovation, continuity and compromise. In M. Caprio \& Y. Sugita (Eds.), Democracy in occupied Japan: The US occupation and Japanese politics and society (pp.1-25). Abingdon, UK: Routledge.

Cumming, A. (2003). Experienced ESL/EFL writing instructors' conceptualization of their teaching: Curriculum options and implications. In B. Kroll (Ed.), Exploring the dynamics of second language writing (pp.71-92). Cambridge, UK: Cambridge University Press.

Dower, J. (1999). Embracing defeat: Japan in the wake of World War II. New York, NY: Norton.

Dörnyei, Z. (2007). Research methods in applied linguistics. Oxford, UK: Oxford University Press.

Drew, P., \& Heritage, J. (1992). Analyzing talk at work: An introduction. In P. Drew \& J. Heritage (Eds.), Talk at work: Interaction in institutional settings (pp. 3-65). Cambridge, UK: Cambridge University Press.

Edwards, R., \& Usher, R. (2008). Globalisation and pedagogy: Space, place and identity (2nd ed.). London, UK: Routledge. 
Fairclough, N. (2001). Language and power. London, UK: Longman.

Freire, P. (2000). Pedagogy of the oppressed (2nd ed.). New York, NY: Continuum.

Gee, J. (2000). The new literacy studies: From 'socially situated' to the work of the social. In D. Barton, M. Hamilton \& R. Ivanic (Eds.), Situated literacies: Reading and writing in context (pp. 180-196). London, UK: Routledge.

Giri, R., \& Foo, J. (2014). On teaching EIL in a Japanese context: the power within and power without. In R. Marlina \& R. Giri (Eds.), The pedagogy of English as an international language (pp. 239-256). Heidelberg, Germany: Springer.

Goodwin, C. (1994). Professional vision. American Anthropologist, 96(3), 606-633.

Gray, A. (2002). Research practice for cultural studies: Ethnographic methods and lived cultures. London, UK: Sage.

Hall, I. (1998). Cartels of the mind: Japan's intellectual closed shop. New York, NY: Norton.

Hashimoto, K. (2007). Japan's language policy and the 'Lost Decade'. In A. Tsui \& J. Tollefson (Eds.), Language policy, culture, and identity in Asian contexts (pp. 25-36). Mahwah, NJ: Erlbaum.

Hayes, D. (2010). Duty and service: life and career of a Tamil teacher of English in Sri Lanka. TESOL Quarterly, 44(1), 58-83.

Heinrich, P. (2012). The making of monolingual Japan: Language ideology and Japanese modernity. Bristol, UK: Multilingual Matters.

Hino, N. (2009). The teaching of English as an international language. AILA Review 22, 103-119.

Iino, M. \& Murata, K. (2016). Dynamics of ELF communication in an English medium academic context in Japan: From EFLlearners to ELF users. In K. Murata (Ed.) Exploring ELF in Japanese academic and business contexts: conceptualization, research and pedagogic implications (pp. 111-132). London, UK: Routledge.

Jenkins, J. (2014). English as a lingua franca in the international university: The politics of academic English language policy. London, UK: Routledge. 
Kubota, R. (2002). The impact of globalization on language teaching in Japan. In D. Block \& D. Cameron (Eds.), Globalization and language teaching (pp. 13-28). London, UK: Routledge.

Kubota, R. (2011a). Questioning linguistic instrumentalism: English, neoliberalism, and language tests in Japan. Linguistics and Education, 22, 248-260.

Kubota, R. (2011b). The politics of school curriculum and assessment in Japan. In Y. Zhao, J. Lei, G. Li, M. He, K. Okano, D. Gamage, H. Ramanathan \& N. Magahed (Eds.), Handbook of Asian education: A cultural perspective (pp. 241-230). New York, NY: Routledge.

Kubota, R., \& Fujimoto, D. (2013). Racialized native speakers: Voices of Japanese-American English language professionals. In S. Houghton \& D. Rivers (Eds). Native-speakerism in Japan:Intergroup dynamics in foreign language education (pp. 75-91). Bristol, UK: Multilingual Matters.

Land, R., \& Whitley, C. (1998). Evaluating second language essays in regular composition classes: Towards a pluralistic U.S.rhetoric. In V.Zamel \& R. Spack (Eds.), Negotiating academic literacies: Teaching and learning across languages and cultures (pp. 135-144). Mahwah, NJ: Erlbaum.

Lea, M., \& Street, B. (2000). Student writing and staff feedback in higher education: An academic literacies approach. In M. Lea and B. Stierer (Eds.), Student writing in higher education (pp. 32-46). Buckingham, UK: Open University.

Lillis, T. (2003). Student writing as academic literacies: Drawing from Bakhtin to move from critique to design. Language and Education, 17(3), 192-207.

Lillis, T., \& Turner, J. (2001). Student writing in higher education: contemporary confusion, traditional concerns. Teaching in Higher Education, 6(11), 57-68.

Lin, A., \& Luk, J. (2005). Local creativity in the face of global domination: Insights of Bakhtin for teaching English for dialogic communication. In J. Hall, G. Vitanova \& L. Marchenkova (Eds.), Dialogue with Bakhtin on second and foreign language learning: New perspectives (pp. 77-98). Mahwah, NJ: Erlbaum. 
Masutani, M. (2013, September 2). Japan Inc. supports education measures. The Japan Times. Retrieved from http://info.japantimes.co.jp/ads/ pdf/20130902_global_30_universities.pdf

McVeigh, B. (2000). Education reform in Japan: Fixing education or fostering economic nation-statism? In J. Eades, T. Gill, \& H. Befu (Eds.), Globalization and social change in contemporary Japan (pp. 7692). Melbourne, Australia: Transpacific.

McVeigh, B. (2002). Japanese higher education as myth. New York, NY: Sharpe.

McVeigh, B. (2006). The state bearing gifts: Deception and disaffection in Japanese higher education. Lanham, MD: Lexington.

Murphey, T. (2004). Participation, (dis-)identification, and Japanese university entrance exams. TESOL Quarterly, 38(4), 700-710.

Peters, M., \& Roberts, P. (2012). The virtues of openness: Education, science and scholarship in a digital age. Boulder, CO: Paradigm.

Rivers, D. (2010). Ideologies of internationalization and the treatment of diversity within Japanese higher education. Journal of Higher Education Policy and Management, 32(5), 442-454.

Rivers, D. (2013). Institutionalized native-speakerism: Voices of dissent and acts of resistance. In S. Houghton \& D. Rivers (Eds.), Nativespeakerism in Japan: Intergroup dynamics in foreign language education (pp. 75-91). Bristol, UK: Multilingual Matters.

Scott, M., \& Turner, J. (2004). Creativity, conformity, and complexity in academic writing: Tensions at the interface. In M. Baynham, A. Deignan \& G. White (Eds.), Applied linguistics at the interface (pp. 145-155). London, UK: Equinox.

Spack, R. (1998). The (in)visibility of the person(al) in academe. In V. Zamel \& R. Spack (Eds.), Negotiating academic literacies: Teaching and learning across languages and cultures (pp. 293-316). Mahwah, NJ: Erlbaum.

Stewart, T. (2001). Raising the status of ESP educators through integrated team teaching. AJELT, 11, 45-67.

Street, B. (1999). Academic literacies. In C. Jones, J. Turner \& B. Street (Eds.), Students writing at the university: Cultural and epistemological issues (pp. 193-199). Amsterdam, the Netherlands: Benjamins. 
Sugimoto, Y. (2010). An introduction to Japanese society. Cambridge, UK: Cambridge University Press.

Thompson, J. (1987). Language and ideology: A framework for analysis. Sociological Review, 35(3), 516-536.

Toh, G. (2013). Where realities confront ideals: The personal, professional, philosophical and political in the teaching of academic English in a Japanese setting. Policy Futures in Education, 11(5), 589-605.

Yamagami, M., \& Tollefson, J. (2011). Elite discourses of globalization in Japan: The role of English. In P. Seargeant (Ed.), English in Japan in the era of globalization (pp. 15-37). New York, NY: Macmillan.

Zamel, V. (1998a). Questioning academic discourse. In V. Zamel \& R. Spack (Eds.), Negotiating academic literacies: Teaching and learning across languages and cultures (pp. 187-197). Mahwah, NJ: Erlbaum.

Zamel, V. (1998b). Strangers in academia: The experience of faculty and ESL students across the curriculum. In V. Zamel \& R. Spack (Eds.), Negotiating academic literacies: teaching and learning across languages and cultures (pp. 249-264). Mahwah, NJ: Erlbaum. 